\title{
The impact of the oral cavity in febrile neutropenia and infectious complications in patients treated with myelosuppressive chemotherapy
}

\author{
Judith A. E. M. Zecha ${ }^{1}$ (D) J Judith E. Raber-Durlacher ${ }^{1,2}$ - Alexa M. G. A. Laheij ${ }^{2} \cdot$ Anneke M. Westermann $^{3}$. \\ Joel B. Epstein ${ }^{4} \cdot$ Jan de Lange ${ }^{1,5} \cdot$ Ludi E. Smeele $^{1,5,6}$
}

Received: 30 March 2019 / Accepted: 5 June 2019 / Published online: 20 June 2019

(C) The Author(s) 2019

\begin{abstract}
Febrile neutropenia (FN) is an inflammatory response causing fever that may develop during cancer therapy-induced neutropenia. FN may herald life-threatening infectious complications and should therefore be considered a medical emergency. Patients presenting with FN are routinely subjected to careful history taking and physical examination including X-rays and microbiological evaluations. Nevertheless, an infection is documented clinically in only $20-30 \%$ of cases, whereas a causative microbial pathogen is not identified in over $70 \%$ of FN cases. The oral cavity is generally only visually inspected. Although it is recognized that ulcerative oral mucositis may be involved in the development of FN, the contribution of infections of the periodontium, the dentition, and salivary glands may be underestimated. These infections can be easily overlooked, as symptoms and signs of inflammation may be limited or absent during neutropenia. This narrative review is aimed to inform the clinician on the potential role of the oral cavity as a potential source in the development of FN. Areas for future research directed to advancing optimal management strategies are discussed.
\end{abstract}

Keywords Febrile neutropenia $\cdot$ Oral infection $\cdot$ Dental health $\cdot$ Oral mucositis $\cdot$ Cancer chemotherapy

\section{Introduction}

Fever is a manifestation of multiple pathways including the release of pro-inflammatory cytokines (including interleukin (IL)-1, IL-6, and tumor necrosis factor (TNF)-alpha) as a consequence of infection or inflammation [1]. Fever that develops

Judith A. E. M. Zecha

j.zecha@amc.uva.nl

Judith E. Raber-Durlacher

j.e.raberdurlacher@amc.uva.nl

Anneke M. Westermann

a.m.westermann@amc.uva.nl

Joel B. Epstein

jepstein@coh.org

Ludi E. Smeele

1.smeele@nki.nl

1 Department of Oral and Maxillofacial Surgery, Amsterdam UMC, University of Amsterdam, Meibergdreef 9, 1105

AZ Amsterdam, The Netherlands during cytotoxic cancer therapy-induced neutropenia, or "febrile neutropenia" (FN), is a medical emergency. FN may be an early and only indication of a serious infection, since profoundly neutropenic patients are unable to mount a robust inflammatory response, and signs and symptoms of inflammation are typically attenuated or absent. In these patients,

2 Department of Oral Medicine, Academic Centre for Dentistry Amsterdam, University of Amsterdam and VU University, Amsterdam, The Netherlands

3 Department of Oncology, Amsterdam UMC, University of Amsterdam, Amsterdam, The Netherlands

4 Cedars-Sinai Health System, Los Angeles and City of Hope Cancer Center, Duarte, CA, USA

5 Academic Centre for Dentistry, (ACTA), University of Amsterdam, Amsterdam, The Netherlands

6 Department of Head \& Neck Oncology \& Surgery, Netherlands Cancer Institute- Antoni van Leeuwenhoek, Amsterdam, The Netherlands 
infections may rapidly progress into life-threatening complications (e.g., systemic inflammatory response syndrome (SIRS), (severe) sepsis, and septic shock). It is critical to early recognize FN (oral temperature $>38.5^{\circ} \mathrm{C}$ or two consecutive readings of $>38.0^{\circ} \mathrm{C}$ for $2 \mathrm{~h}$ and an absolute neutrophil count $<500 \mu / \mathrm{L}$ or expected to fall below this threshold), and depending on the estimated risk to develop life-threatening complications, initiate empiric systemic broad-spectrum antibacterial therapy and other supportive care measures promptly [2]. Moreover, FN is associated with higher morbidity, unplanned or prolonged hospitalization, potential intensive care admission, and can necessitate chemotherapy (CT) dose reductions and/or treatment delays, which may lead to poorer clinical outcome and survival $[2,3]$.

If a patient presents with $\mathrm{FN}$ while on myelosuppressive $\mathrm{CT}$, one should assume that this is due to infection, particularly if there is no evidence for an alternative explanation (e.g., transfusion reactions, medication allergies and toxicities, vasculitis or other inflammatory conditions, and tumor(lysis)-related fever) [4]. Nevertheless, patients must be carefully evaluated for potential infection. These patients are routinely subjected to careful history taking, physical examination, chest Xray, and microbiological evaluations. However, infections can be documented clinically in only $20-30 \%$ of febrile episodes, whereas a causative microbial pathogen cannot be identified in the majority $(>70 \%)$ of cases [5-10], and the cause of the fever may remain unidentified (fever of unknown origin; FUO).

Neutropenia risk depends on patient-, tumor-, and treatment-related factors. Although CT dose intensity and myelotoxicity represent significant risk factors, neutropenia and its complications may occur after treatment with almost any type of CT [11]. However, not all neutropenic patients develop fever, and not all episodes of FN progress into lifethreatening sepsis. CT regimens can be classified as high, intermediate, and low risk for FN [12]. Those with $>20 \%$ FN risk are considered high risk. This includes, but is not limited to, patients treated with high-dose CT with or without hematopoietic stem cell transplantation (HSCT). Most CT regimens used for the treatment of adult solid tumors and lymphoma are rated as intermediate (between 10 and 20\%) risk for $\mathrm{FN}$, whereas low-risk cytotoxic regimens are typically considered to be associated with FN risk $<10 \%[13,14]$. Tools aimed to identify patients with FN at low risk of serious complications have been developed [15]. However, identification of high-risk patients remains a challenge [16]. It is well recognized that oral mucositis $(\mathrm{OM})$ as well as gastrointestinal mucositis may cause fever $[17,18]$ and predisposes to systemic translocation of microorganisms $[19,20]$. If a patient presents with $\mathrm{FN}$, the physician routinely performs an oral inspection to assess whether ulcerative OM or mucosal infections are present. However, fever may be also caused by inflammation and infection at other oral sites, including the periodontium, the dentition, and salivary glands. Most frequently, this involves asymptomatic chronic infections that were present before the initiation of CT. These infections may exacerbate and present with redness, swelling, and pain [21], but they may also be asymptomatic or manifest with only minimal signs of inflammation. Nevertheless, these predominantly asymptomatic infections (particularly those of the periodontium) may contribute to systemic inflammation [22] and risk of bacteremia and are associated with FN [23-25]. Unfortunately, these infections likely remain undiagnosed by simple oral inspection [26]. In order to ascertain diagnosis and management of these "hidden" oral infections, the National Institute of Health [27] stated that all patients should receive a comprehensive oral examination by a dental professional and potential foci of infection should be eliminated prior to the start of CT. In most centers, however, this is may be only routinely performed in patients considered at high risk for complications: i.e., patients scheduled for HSCT and those undergoing (chemo)radiation therapy to the head and neck, whereas patients treated with other myelosuppressive CT regimens are not typically referred for pre-treatment oral evaluation. It is thus conceivable that particularly in these patients, FN may have originated from an oral source that remained undiagnosed.

This narrative review is aimed to inform the oncologist of current evidence of the contribution of oral infections and non-infectious conditions (e.g., OM) to the development of $\mathrm{FN}$ and infectious complications associated with myelosuppressive CT. Areas for future research directed to developing optimal management strategies are presented.

\section{The impact of myelosuppressive CT on the oral ecosystem}

Oral homeostasis is maintained due to complex and finely tuned interactions between the host and resident microorganisms. Having cancer, myelosuppressive cancer treatment regimens and concurrent medications, including antibiotics, disturb the equilibrium of the oral ecosystem via direct and indirect mechanisms, and contribute to the development of oral complications and infectious sequelae.

The mouth houses a diverse microbial community, harboring over 700 species of bacteria that colonize the hard surfaces of teeth and soft tissues as biofilms [28]. Residing microbes prevent colonization and overgrowth of opportunistic and pathogenic microorganisms. Studies suggest that treatment with myelosuppressive $\mathrm{CT}$ induces alterations of the oral microbiome (Table 1).

As a result of cytotoxic CT and other concurrent medications, patients may develop hyposalivation (reduced salivary flow) [39]. Saliva has a key role in maintaining a stable oral ecosystem as it contains peptides and proteins that have many 
Table 1 Myelosuppressive CT and its impact on the oral microflora

\begin{tabular}{|c|c|c|}
\hline Author & Results & Patient group \\
\hline Peterson et al. [29] & $\begin{array}{l}\text { Potentially pathogenic bacteria could be identified in } \\
\text { granulocytopenic patients, e.g., } \\
\text { - Staphylococcus spp. } \\
\text { - Gram negative enteric bacilli }\end{array}$ & Acute leukemia \\
\hline Bergmann et al. [30] & $\begin{array}{l}\text { Enterobacteriaceae, Enterococcus faecalis, Candida } \\
\text { spp. Identified following CT }\end{array}$ & Acute leukemia \\
\hline Napenas et al. [31] & $\begin{array}{l}>60 \% \text { of identified species were exclusively } \\
\text { found post-CT }\end{array}$ & Breast cancer \\
\hline Ye et al. [32] & $\begin{array}{l}\text { Decreased oral microbial diversity and shifts in the } \\
\text { microbiological composition }\end{array}$ & Pediatric cancer \\
\hline Galloway-Peña et al. [33] & $\begin{array}{l}\text { Decrease of oral and stool microbial } \alpha \text {-diversity } \\
\text { during remission-induction CT in patients that } \\
\text { developed a microbiologically documented infection }\end{array}$ & Acute myeloid leukemia \\
\hline Dahlen [34] & $\begin{array}{l}\text { Shifts of oral mucosal microflora increases the } \\
\text { likelihood of infections with enterococci and } \\
\text { staphylococci }\end{array}$ & $\begin{array}{l}\text { Immunocompromised patients } \\
\text { receiving cytotoxic } \mathrm{CT}\end{array}$ \\
\hline Kennedy et al. [35] & \multirow{3}{*}{$\begin{array}{l}\text { Bacteremia with CONS may originate from oral } \\
\text { mucosal membranes }\end{array}$} & HSCT [35] \\
\hline Costa et al. [36] & & Immunocompromised patients \\
\hline Soga et al. [37] & & $\begin{array}{l}\text { including cancer patients [36] } \\
\text { HSCT [37] }\end{array}$ \\
\hline Soga et al. [38] & $\begin{array}{l}\text { MRSA was detected in the oral cavity following HSCT, } \\
\text { especially during OM peak severity }\end{array}$ & HSCT \\
\hline
\end{tabular}

CT chemotherapy, CONS coagulase-negative staphylococci, HSCT hematopoietic stem cell transplantation, MRSA methicillin-resistant staphylococcus spp., $O M$ oral mucositis

different qualities. These include antibacterial, antifungal, and antiviral functions as well as lubricant, buffering, remineralization, and digestion properties [40]. A lack of these salivary defense mechanisms may contribute to oral dysbiosis contributing to an increase of the incidence and severity of complications, including OM, oral mucosal infections, and dental caries [41, 42].

\section{The potential contribution of oral sources of infection and inflammation to FN and infectious complications}

The oral cavity is the primary gateway to the human body as it is contiguous with the tonsils, pharynx, esophagus, eustachian tube, middle ear, trachea, lungs, nasal passages, and sinuses. Microorganisms colonizing the oral cavity may migrate via contiguous epithelial surfaces to these anatomical sites [43]. In addition, oral microorganisms and inflammatory products may translocate into the circulation through ulcerated periodontal pockets and breached epithelial lining of mucous membranes and disseminate systemically [44, 45]. This may contribute to fever and infectious complications in neutropenic or otherwise immunocompromised patients $[23,46,47]$ and has been reported to contribute to increased risk to early non-tumorrelated mortality in HSCT recipients [48-50].

\section{Oral mucositis}

$\mathrm{OM}$ is an inflammatory condition of the oral mucosa induced by $\mathrm{CT}$ and/or radiation therapy. Most often, it manifests at the buccal and labial surfaces, ventral surface of the tongue, floor of the mouth, and the soft palate [51]. Mucosal changes can range from erythema to extensive ulcerations and hemorrhage. Patients experience $\mathrm{OM}$ as a painful condition associated with significant suffering and a negative impact on the quality of life [51, 52]. Ulcerative OM may not only act as a portal of entry for microorganisms and inflammatory products, but as it often compromises food intake, oral medication use, and oral hygiene, it may also contribute indirectly to infection risk $[52,53]$.

The majority of patients treated with high-dose CT regimens (with or without HSCT) develop OM (all grades), whereas its incidence in less intensive forms of CT is estimated to vary between 0 and $52 \%[54,55]$ (summarized in Table 2).

There is a temporal relationship between having ulcerative mucositis, fever, and neutropenia [48, 60-62]. However, the role of neutrophils in the pathogenesis and resolvent of $\mathrm{OM}$ has not yet been fully elucidated, and studies on granulocyte stimulating growth factors for the prevention and treatment of OM show conflicting results [25].

Sonis suggested that cells rendered apoptotic or necrotic by CT, release CT-associated molecular patterns ("CRAMPs"), which play an important role in initiating inflammation [63]. 
Table 2 The frequency of oral mucositis (all grades) among patients treated with chemotherapy for different types of malignancies

\begin{tabular}{|c|c|c|c|}
\hline Author & Oral mucositis incidence $(\%)$ & Patient group & Chemotherapy regimen \\
\hline Jensen et al. [56] & 22 & Breast cancer & $\begin{array}{l}\text { Cyclophosphamide, epirubicin or methotrexate, } \\
\text { and 5-fluorouracil }\end{array}$ \\
\hline Al Ibraheemi et al. [57] & 81.3 & Breast cancer & Adriamycine, cyclophosphamide, and taxane \\
\hline Nishimura et al. [58] & $\begin{array}{l}76.5 \\
63 \\
57.8 \\
42.9\end{array}$ & $\begin{array}{l}\text { Breast cancer } \\
\text { Colorectal cancer } \\
\text { Esophageal cancer } \\
\text { Malignant lymphoma }\end{array}$ & $\begin{array}{l}\text { CAF regimen; cyclophosphamide, } \\
\text { doxorubin hydrochloride, 5-FU } \\
\text { AC; doxorubicin hydrochloride, } \\
\text { cyclophosphamide } \\
\text { FOLFIRI regimen; irinotecan, leucovorin, } \\
\text { bolus 5-FU and a 46-h infusion of 5-FU } \\
\text { FOLFOX } 4 \text { regimen; oxiliplatin, leucovorin, } \\
\text { bolus 5-FU and a 46-h infusion of 5-FU } \\
\text { Not described } \\
\text { R-CHOP regimen; rituximab, cyclophosphamide, } \\
\text { doxorubicin hydrochloride, vincristine sulfate, } \\
\text { prednisone (weekly rituximab clinical trial setting). }\end{array}$ \\
\hline Laine et al. [59] & 43.4 & Lymphoma & $\begin{array}{l}\text { Hodgkin: ABVD; doxorubicin, bleomycin, } \\
\text { velbedacarbazine, or (MOPP)-ABV; mustine, } \\
\text { oncocine, procarbazine, prednisone } \\
\text { Non-Hodgkin: M-BACOD or M-BECOD; } \\
\text { methotrexate, bleomycin, doxorubicin, } \\
\text { epiadriamycin, cyclophosphamide, oncovin, } \\
\text { dexamethasone }\end{array}$ \\
\hline Khan and Wingard. [54] & $\begin{array}{l}75 \\
>66 \\
33 \\
40\end{array}$ & $\begin{array}{l}\text { Bone marrow transplantation } \\
\text { Leukemia } \\
\text { Non-Hodgkin lymphoma } \\
\text { Solid tumors }\end{array}$ & Not described \\
\hline
\end{tabular}

When pattern recognition receptors (PRRs) expressed by cells of the innate immune system within the mucosa (e.g., macrophages, neutrophils, and dendritic cells) are exposed to CRAMPS, this results in the release of cytokines that act locally, and also may have distant effects by activating intracellular and intercellular signaling loops [64]. These include the hypothalamic-pituitary-adrenal axis resulting in fever, and effects on the liver resulting in the generation of acute phase proteins. All of which can ultimately result in SIRS and sepsis. Indeed, Blijlevens and colleagues reported that mucositis induces a systemic inflammatory response characterized by fever in neutropenic HSCT recipients, even in the absence of bacteremia [17, 18].

Although OM is not an infectious process, studies suggest that poor oral hygiene and pre-existing oral infections aggravate the severity and duration of toxicity induced mucosal reaction and thereby contribute to the risk to develop FN and infectious complications [53, 65-72] (Table 3).

\section{Oral mucosal infections}

In addition to FN associated with $\mathrm{OM}$, oral mucosal ulcerations with a non-mucositis etiology may induce FN. However, from a clinical perspective, it can be difficult to discriminate between such lesions as they may develop simultaneously.
Herpes simplex virus (HSV) is a major pathogen causing mucosal ulceration that may be confused with OM or may aggravate this condition [78]. Most HSV infections occur as a result of reactivation of latent virus in HSV seropositive patients. Upregulation of NF- $\mathrm{KB}$ resulting in loss of mucosal barrier in OM may also induce signaling pathways that stimulate virus reactivation [79]. HSV reactivation can be controlled with antiviral prophylaxis or treatment in most patients, although reactivation is still possible despite prophylaxis [54]. Herpetic lesions in patients receiving CT can be painful and may be associated with hemorrhage and necrosis, and bacterial and fungal superinfections. In myelosuppressed patients, HSV infection has atypical clinical manifestations, mainly manifesting as intraoral ulcerations with or without labial involvement. HSV infection may develop at sites, which are usually not affected by OM (e.g., the dorsum of the tongue, gingiva, and the hard palate). Herpetic lesions in compromised hosts may persist for extended periods until recovery from myelosuppression or appropriately treated.

In addition, other herpesviruses, Epstein-Barr Virus (EBV) in particular, may predispose for developing oral mucosal ulcerations during neutropenia and thus may directly or indirectly play a role in FN originating from the oral cavity [80]. Periodontal pockets [81] and salivary glands seem important reservoirs of cytomegalovirus (CMV) [82]. The virus can be shed (via gingival crevicular fluid and salivary glands) in 
Table 3 Studies reporting a relationship between oral health and oral mucositis, potentially resulting in fever and infectious complications

\begin{tabular}{|c|c|c|}
\hline Author & Results & Patient group \\
\hline Fernándes et al. [67] & $\begin{array}{l}\text { All patients with periodontitis prior to conditioning } \\
\text { therapy developed OM. The presence of gingivitis } \\
\text { was significantly associated with the frequency of OM }\end{array}$ & HSCT \\
\hline Coracain et al. [71] & $\begin{array}{l}\text { Patients oral health was predictive of the incidence and } \\
\text { severity of OM }\end{array}$ & HSCT \\
\hline Kashiwazaki et al. [53] & \multirow{2}{*}{$\begin{array}{l}\text { Treatment of dental pathologies and reducing the oral } \\
\text { microbial load resulted in reduction of incidence and } \\
\text { severity of OM }\end{array}$} & HSCT [53] \\
\hline $\begin{array}{l}\text { Epstein and } \\
\text { Schubert [73] }\end{array}$ & & $\begin{array}{l}\text { Hematologic } \\
\text { malignancies [73] }\end{array}$ \\
\hline Kashiwazaki et al. [53] & $\begin{array}{l}\text { Maximal CRP levels in peripheral blood and incidence } \\
\text { of FN is significantly lower in the group who } \\
\text { performed intensive oral hygiene }\end{array}$ & HSCT \\
\hline Santos et al. [70] & $\begin{array}{l}\text { Treatment of dental pathologies and reducing oral } \\
\text { microbial load resulted in shorter duration of OM }\end{array}$ & HSCT \\
\hline $\begin{array}{l}\text { Khan and } \\
\text { Wingard [54] }\end{array}$ & $\begin{array}{l}\text { Presence of oropharyngeal mucositis is an independent } \\
\text { risk factor for bacteremia in neutropenic patients }\end{array}$ & $\begin{array}{l}\text { HSCT, non-Hodgkin } \\
\text { lymphoma, } \\
\text { leukemia }\end{array}$ \\
\hline Laine et al. [23, 59] & $\begin{array}{l}\text { Association between the presence of oral mucosal ulcers } \\
\text { and episodes of fever and sepsis }\end{array}$ & Lymphoma \\
\hline $\begin{array}{l}\text { Sonis et al. [48] } \\
\text { Schuurhuis et al. [62] }\end{array}$ & $\begin{array}{l}\mathrm{OM} \text { is associated with higher FN risk as compared with } \\
\text { patients without OM }\end{array}$ & $\begin{array}{l}\text { Hematologic } \\
\text { malignancies }\end{array}$ \\
\hline Ruescher et al. [19] & \multirow{4}{*}{$\begin{array}{l}\text { OM was most likely origin of bacteremia with oral } \\
\text { viridans streptococci, frequently resulting in fever } \\
\text { and potentially leading to ARDS and septic shock }\end{array}$} & HSCT [19] \\
\hline Elting et al. [74] & & Patients treated \\
\hline Bochud et al. [75] & & with CT $[74,75]$ \\
\hline Marron et al. [76] & & $\begin{array}{l}\text { Hematologic } \\
\text { malignancies [76] }\end{array}$ \\
\hline Ebinuma et al. [77] & $\begin{array}{l}\text { Maintenance of good oral hygiene may reduce the gene } \\
\text { mediating methicillin resistance. The oral cavity may } \\
\text { act as a reservoir for harboring this gene }\end{array}$ & HSCT \\
\hline
\end{tabular}

$F N$ febrile neutropenia, $O M$ oral mucositis, $H S C T$ hematopoietic stem cell transplantation, CRP C-reactive protein, $A R D S$ acute respiratory distress syndrome, $C T$ chemotherapy whole saliva forming a main mechanism for transmitting CMV. CMV induces local production of pro-inflammatory cytokines and remains a major cause of morbidity in HSCT recipients [83].

Oral candidiasis is typically caused by opportunistic overgrowth of Candida albicans, C. krusei, C. tropicalis, C. dubliniensis, and other commensal oral yeasts. Neutropenia, mucosal damage, depressed cell-mediated immunity, hyposalivation, immunosuppressive medications, and use of antibiotics are risk factors. The most common forms are pseudomembranous and erythematous candidiasis [84]. During oral infection with Candida spp., a large amount of inflammatory cytokines is generated in the oral mucosa, potentially inducing fever $[85,86]$. Current prophylactic strategies have reduced systemic candidiasis, although oral and oropharyngeal candidiasis still may have serious consequences. Good oral hygiene is important in addition to antifungal therapy.

Rarely, molds, such as Zygomycetes, Coccidiomycosis, histoplasmosis, and Aspergillus spp., cause oral infections. Typical lesions include ulcers in the oral cavity, tongue, or gingival regions that may progress into invasion of deep tissues, including bone. Early recognition (and confirmation by biopsy), aggressive debridement, and antifungal therapy with extended spectrum azoles are paramount [87].

\section{Dental pathologies}

Pre-existing dental pathologies that may cause FN and infectious complications during myelosuppressive CT include periodontal disease, profound dental caries, and periapical pathology due to infection of the root canal, (partially) impacted teeth, and retained roots [88].

\section{Periodontal disease}

Gingivitis is a localized or generalized inflammation of the gingiva without loss of periodontal attachment, whereas periodontitis is a chronic inflammation of the gingiva, affecting the deeper parts of the periodontium. As dental plaque migrates in apical direction, periodontal attachment degrades, leading to ulcerative periodontal pockets, bone resorption, and tooth loss. About $40-50 \%$ of adults has chronic gingivitis, around $35 \%$ suffer from moderate periodontitis, whereas the prevalence of severe periodontitis is estimated to range from 
Table 4 Presence of periodontal disease and associations with bacteremia, FN, and infectious complications

\begin{tabular}{lll}
\hline Author & Results & Patient group \\
\hline $\begin{array}{l}\text { Fernándes et al. [67] } \\
\text { Soga et al. 2009 [24] }\end{array}$ & $\begin{array}{c}\text { Presence of periodontitis is associated with } \\
\text { the development of bacteremia. }\end{array}$ & HSCT \\
$\begin{array}{l}\text { Raber-Durlacher et al. [96] } \\
\text { Laine et al. [23] }\end{array}$ & $\begin{array}{l}\text { In 58\% of the febrile episodes, mild to } \\
\text { moderate gingivitis was present }\end{array}$ & Lymphoma \\
& $\begin{array}{l}\text { In 33\% of the febrile episodes, severe } \\
\text { gingivitis was present }\end{array}$ & Pediatric malignancies \\
Hong et al. [97] & $\begin{array}{l}\text { 20.3\% of patients had severe gingivitis } \\
\text { Peterson and Overholser [98] }\end{array}$ & $\begin{array}{l}\text { Gingivitis and periodontitis were found } \\
\text { to be associated with bacteremia, fever, }\end{array}$ \\
$\begin{array}{l}\text { Greenberg et al. [65] } \\
\text { and sepsis in neutropenic patients }\end{array}$ & \\
$\begin{array}{l}\text { Overholser et al. [99] } \\
\text { Bergmann et al. [46] }\end{array}$ & & \\
Laine et al. [23] & & \\
Meurman et al. [100] & & Head and neck cancer \\
Soga et al. [24] & FN may be induced by periodontal \\
Russi et al. [64] & inflammation and infection & \\
\hline
\end{tabular}

$F N$ febrile neutropenia, $H S C T$ hematopoietic stem cell transplantation
10 to $15 \%$ in Western populations [26]. Periodontitis risk increases with age (peaks between 50 and 60 years) and is more prevalent in men than in women. The severity of the periodontal disease depends on environmental and host factors (e.g., genetic susceptibility, comorbidities, oral hygiene, and smoking) [89]. Inflamed and infected periodontal tissues can expose up to $35-50 \mathrm{~cm}^{2}$ of connective inflamed tissue and may serve as a reservoir of endotoxin (lipopolysaccharide), pro-inflammatory cytokines, and proteolytic enzymes that may spread systemically via ulcerated pocket epithelium and contribute to endothelial dysfunction, a pro-coagulant state, and low-level inflammation [90, 91]. Periodontal infection has been associated with bacteremic seeding of heart valves and prosthetic devices [92], FUO, and a wide range of systemic conditions, including ischemic cardiovascular disease, metabolic syndrome and type 2 diabetes, rheumatoid arthritis, and respiratory diseases, including aspiration pneumonia [93-95].

Table 4 summarizes the literature on gingivitis and periodontitis and their association with bacteremia, FN and infectious complications.

Ulcerated periodontal pocket epithelium can allow translocation of microorganisms into the bloodstream [101]. Bacteremia may be caused by facultative or strictly anaerobic bacteria likely originating from the periodontium, including Capnocytophaga spp. and Fusobacterium nucleatum [102-106]. However, bacteremia with these microorganisms is relatively uncommon, whereas bacteremias with viridans streptococci and CONS occur frequently in profoundly myelosuppressed patients. Increases of gingival viridans streptococci and CONS have been documented during highdose CT [29], and one study reported that periodontitis may contribute to the risk of bacteremia with viridans streptococci and CONS during the neutropenic phase of HSCT [107]. Periodontal disease may be occult without symptoms and clinical signs that may only be detected upon comprehensive periodontal evaluation and not identified based on general oral examination.

\section{Miscellaneous odontogenic infections}

A number of studies on the potential role of odontogenic infections in the development of FN do not distinguish between periodontal disease and other infections related to the dentition (Table 5).

\section{Discussion and recommendations for future research}

There is evidence suggesting that infectious and inflammatory processes of the oral cavity may contribute to $\mathrm{FN}$, particularly in patients treated with high-dose CT with or without HSCT. However, most studies are retrospective and include only a small number of patients. Well-powered, prospective observational studies in homogenous groups of patients, including those treated with myelosuppressive CT for solid tumors, are needed to obtain a better understanding of the contribution of $\mathrm{OM}$ and oral infections to $\mathrm{FN}$ and its potential sequelae.

Particularly, OM $[17,18]$ and periodontal disease $[23,24$, $46,64,65,67,96,98-100]$ seem important in the development of FN, whereas the literature on other potential oral sources of FN (such as mucosal infections, periapical pathologies, and pericoronitis) is scarce. Some studies report 
Table 5 Presence of miscellaneous odontogenic infections and associations with bacteremia, FN, and infectious complications

\begin{tabular}{|c|c|c|}
\hline Author & Results & Patient group \\
\hline Greenberg et al. [65] & $\begin{array}{l}\text { Patients who did not receive dental treatment prior to CT: } \\
\text { - In } 77 \% \text { of patients, sepsis occurred. } \\
\text { - } 67 \% \text { of patients developed acute exacerbations of oral bacterial infections. } \\
\text { Patients in which dental infections were treated before CT: } \\
\text { - In } 25 \% \text { of the patients, sepsis occurred. } \\
\text { - No acute exacerbations of oral bacterial infections occurred. }\end{array}$ & Acute leukemia \\
\hline Laine et al. [23] & $\begin{array}{l}\text { Patient with febrile episodes had more severe dental pathologies than those } \\
\text { without fever ( } 57.6 \% \text { vs } 23.3 \% \text { ) }\end{array}$ & Lymphoma \\
\hline Toljanic et al. [108] & Incidence of acute dental problems during febrile episodes of $4 \%$ & Solid and hematologic malignancies \\
\hline Akintoye et al. [109] & $\begin{array}{l}23 \text { out of } 49 \text { positive blood cultures with microorganisms were likely to } \\
\text { originate from the oral cavity; } 20 \text { of these bacteremias the periodontium } \\
\text { was the most likely origin. }\end{array}$ & HSCT \\
\hline Cullen et al. [6] & $\begin{array}{l}\text { In } 5 \% \text { of febrile episodes an oral infection was thought to be the focus } \\
\text { of infection }\end{array}$ & Solid tumors and lymphomas \\
\hline Hong et al. [97] & Weighted prevalence of dental infections of $5.8 \%$ & Patients treated with cytotoxic $\mathrm{CT}$ \\
\hline Hong et al. [110] & $\begin{array}{l}\text { Weighted prevalence of dental infections was } 5.4 \% \text {; pericoronitis was } \\
\text { present in } 5.3 \% \text { of patients }\end{array}$ & Patients treated with cytotoxic $\mathrm{CT}$ \\
\hline Schuurhuis et al. [62] & $\begin{array}{l}\text { Prevalence of } 4 \% \text { of acute exacerbations of chronic oral foci. concluded } \\
\text { that asymptomatic chronic oral infections, that had not exacerbated in } \\
\text { the previous } 3 \text { months, could safely be left untreated without increasing } \\
\text { the infectious complications. }\end{array}$ & $\begin{array}{l}\text { Hematologic cancers receiving intensive } \\
\text { CT with or without HSCT }\end{array}$ \\
\hline Tsuji et al. [111] & $\begin{array}{l}\text { Significant higher incidence of systemic infectious and/or inflammatory } \\
\text { parameters (temperature }>38.0 \mathrm{C} \text {, presence of respiratory symptoms, } \\
\text { elevated CRP levels and positive blood cultures) in patients with oral } \\
\text { foci of infections, particularly during the first cycle of CT inducing } \\
\text { profound myelosuppression. }\end{array}$ & Hematologic malignancies \\
\hline Akashi et al. [112] & $\begin{array}{l}\text { Development of septic shock in } 2 \text { patients of which it was assumed that } \\
\text { this was associated with a chronic odontogenic infection. No bacterial } \\
\text { evidence was found from the blood cultures. }\end{array}$ & Hematologic malignancies \\
\hline
\end{tabular}

FN febrile neutropenia, CT chemotherapy, HSCT hematopoietic stem cell transplantation

infrequent conversion of chronic dental disease to an acute state during $\mathrm{CT}$ and conclude that there is no need for the treatment of "asymptomatic" chronic dental infections prior to CT or conditioning therapy for HSCT $[62,108]$. However, studies should not focus solely on these acute exacerbations, associated with swelling and pain, since the inflammatory response may be muted or absent due to myelosuppression. It is essential that endpoints of future studies should also include the presence of "asymptomatic" disease, particularly chronic periodontitis which requires comprehensive examination including periodontal probing and appropriate dental imaging.

There is convincing evidence from the periodontal literature that gingivitis as well as periodontitis induces frequent episodes of bacteremia during daily activities such as chewing and tooth brushing $[44,113]$. In non-myelosuppressed individuals, these episodes of bacteremia are typically transient. In myelosuppressed and otherwise immunocompromised cancer patients, however, bacteremia risk is likely increased as in addition to breached epithalial barriers, these patients are less capable of clearance of microorganisms from the blood stream, and infectious complications may develop. In addition to hematogenous spread of oral microorganisms and inflammatory mediators, there is evidence that poor oral and dental conditions may predispose for aspiration pneumonia [94, 114].

Systemic dissemination of oral microorganisms should be investigated in more detail in cancer patients treated with myelosuppressive CT. Future investigations, using new open-end next-generation sequencing techniques, should aim to further characterize the role of the oral/periodontal microbiome in the pathobiology of mucositis as well as in systemic infectious complications. Among other factors, the use of prophylactic antibiotics has changed the spectrum of isolated pathogens from the bloodstream as the most common causes of bacteremia in myelosuppressed cancer patients are coagulasenegative staphylococci, viridans group streptococci, and enterococci [9], which may all originate from the periodontium and oral mucosa [31, 37, 46, 115-119]. Particularly, the contribution of Staphylococcus epidermidis originating from the oral cavity should be studied.

An intriguing hypothesis that needs further exploration is the concept that inflammatory complications induced by cytotoxic cancer therapies may have a common pathobiological background and share genetically determined risk factors [64]. Inflammation, particularly an imbalance between upregulated 
pro-inflammatory cytokine pathways and suppressed antiinflammatory cytokines, may be a major common driver of these complications [120]. In addition, macrophages have been identified to play a critical role in the potential bidirectional links between periodontal and systemic inflammatory diseases [121]. It has been proposed that the presence of inflammation (anywhere in the body) primes for a dysregulated and exaggerated inflammatory response following a subsequent inflammatory stimulus [122]. This "two-hit model" has been hypothesized to underpin a potential association between periodontitis and OM [123]. Moreover, it has been suggested that patients with periodontitis are more prone to developing fever and septic shock syndrome, since endotoxins derived from periodontal pockets may lead to precipitating conditions [124]. These intriguing findings and hypotheses deserve further exploration.

An important clinical question concerns the management of potential oral foci of FN. There is a consensus that patients planned to be treated with high-dose CT with or without HSCT, or those who will be treated with curative (chemo)radiation for head and neck cancers should be referred to a dental professional for a comprehensive oral and periodontal pre-treatment evaluation with appropriate treatment. In patients with head and neck cancers, rigorous elimination of potential foci of infection (i.e., in most cases by extraction) is mandatory in patients with at-risk conditions in the radiation volume [125], whereas in other patient categories, protocols may be less rigid. There is substantial evidence suggesting that intensive oral care performed before and during cancer treatment results in a reduction of infectious complications [24, 53, $66,68,126-128]$. Elad and coworkers [129] developed a predictive model suggesting that no dental treatment increased the probability of dying due to a dental/periodontal infection in HSCT recipients. In selected cases, treatment of periodontal infections by debridement and reducing the oral bacterial load, and endodontic treatments may be preferred over extractions. In addition, approaches aimed at resolving periodontal inflammation hold significant promise [130]. These interventions may also positively affect $\mathrm{OM}$. When FN (likely) originating from the oral cavity develops during CT treatment, antimicrobial therapy should be preferably based on microbiological evaluation of swabs and/or oral rinsing samples.

In conclusion, current recommendations for the prevention of complications include dental evaluation and work up of high-risk patients as an integrated part of the patient workup and management. Nevertheless, large longitudinal studies are needed to obtain more insight in the relative contribution of oral pathologies to $\mathrm{FN}$ and infectious complications. Particularly, in patients treated with myelosuppressive CT for solid tumors information is scarce. In addition, more information is needed on the impact of myelosuppressive CT and other medications (i.e., antibiotics) on the oral microbiome and systemic translocation of oral microorganisms. Lastly, studies should be directed to obtain a better insight in individual risk factors of patients and to develop optimal personalized oral care strategies.

Acknowledgements We kindly acknowledge support from the Eklund Foundation.

\section{Compliance with ethical standards}

Conflict of interest The authors declare that they have no conflict of interest.

Open Access This article is distributed under the terms of the Creative Commons Attribution 4.0 International License (http:// creativecommons.org/licenses/by/4.0/), which permits unrestricted use, distribution, and reproduction in any medium, provided you give appropriate credit to the original author(s) and the source, provide a link to the Creative Commons license, and indicate if changes were made.

\section{References}

1. Netea MG, Kullberg BJ, Van der Meer JW (2000) Circulating cytokines as mediators of fever. Clin Infect Dis 31(Suppl 5): S178-S184. https://doi.org/10.1086/317513

2. Kuderer NM, Dale DC, Crawford J, Cosler LE, Lyman GH (2006) Mortality, morbidity, and cost associated with febrile neutropenia in adult cancer patients. Cancer 106(10):2258-2266. https://doi. org/10.1002/cncr.21847

3. Marti FM, Cullen MH, Roila F (2009) Management of febrile neutropenia: ESMO clinical recommendations. Annals of oncology : official journal of the European Society for Medical Oncology 20(Suppl 4):166-169. https://doi.org/10.1093/annonc/ mdp163

4. Flowers CR, Seidenfeld J, Bow EJ, Karten C, Gleason C, Hawley DK, Kuderer NM, Langston AA, Marr KA, Rolston KV, Ramsey SD (2013) Antimicrobial prophylaxis and outpatient management of fever and neutropenia in adults treated for malignancy: American Society of Clinical Oncology clinical practice guideline. J Clin Oncol 31(6):794-810. https://doi.org/10.1200/jco.2012.45. 8661

5. Schelenz S, Giles D, Abdallah S (2012) Epidemiology, management and economic impact of febrile neutropenia in oncology patients receiving routine care at a regional UK cancer centre. Annals of oncology : official journal of the European Society for. Med Oncol 23(7):1889-1893. https://doi.org/10.1093/ annonc/mdr520

6. Cullen M, Steven N, Billingham L, Gaunt C, Hastings M, Simmonds P, Stuart N, Rea D, Bower M, Fernando I, Huddart R, Gollins S, Stanley A (2005) Antibacterial prophylaxis after chemotherapy for solid tumors and lymphomas. N Engl J Med 353(10):988-998. https://doi.org/10.1056/NEJMoa050078

7. Jeddi R, Achour M, Amor RB, Aissaoui L, Bouteraa W, Kacem K, Lakhal RB, Abid HB, BelHadjAli Z, Turki A, Meddeb B (2010) Factors associated with severe sepsis: prospective study of 94 neutropenic febrile episodes. Hematology 15(1):28-32. https:// doi.org/10.1179/102453310x12583347009577

8. Freifeld AG, Bow EJ, Sepkowitz KA, Boeckh MJ, Ito JI, Mullen CA, Raad II, Rolston KV, Young JA, Wingard JR (2011) Clinical practice guideline for the use of antimicrobial agents in neutropenic patients with cancer: 2010 update by the Infectious Diseases 
Society of America. Clin Infect Dis 52(4):427-431. https://doi. org/10.1093/cid/ciq147

9. Koinis F, Nintos G, Georgoulias V, Kotsakis A (2015) Therapeutic strategies for chemotherapy-induced neutropenia in patients with solid tumors. Expert Opin Pharmacother 16(10):1505-1519. https://doi.org/10.1517/14656566.2015.1055248

10. JR TJaW (2003) Infectious syndrome in solid tumour therapy. Management of infection in oncology patients:55-70

11. Ray-Coquard I, Borg C, Bachelot T, Sebban C, Philip I, Clapisson G, Le Cesne A, Biron P, Chauvin F, Blay JY (2003) Baseline and early lymphopenia predict for the risk of febrile neutropenia after chemotherapy. Br J Cancer 88(2):181-186. https://doi.org/10. 1038/sj.bjc.6600724

12. Dale DC (2003) Optimizing the management of chemotherapyinduced neutropenia. Clin Adv Hematol Oncol 1(11):679-684

13. Lyman GH, Abella E, Pettengell R (2014) Risk factors for febrile neutropenia among patients with cancer receiving chemotherapy: a systematic review. Crit Rev Oncol Hematol 90(3):190-199. https://doi.org/10.1016/j.critrevonc.2013.12.006

14. Pettengell R, Schwenkglenks M, Leonard R, Bosly A, Paridaens R, Constenla M, Szucs TD, Jackisch C (2008) Neutropenia occurrence and predictors of reduced chemotherapy delivery: results from the INC-EU prospective observational European neutropenia study. Supportive care in cancer : official journal of the Multinational Association of Supportive Care in Cancer 16(11): 1299-1309. https://doi.org/10.1007/s00520-008-0430-4

15. Klastersky J, Paesmans M, Rubenstein EB, Boyer M, Elting L, Feld R, Gallagher J, Herrstedt J, Rapoport B, Rolston K, Talcott J (2000) The Multinational Association for Supportive Care in Cancer risk index: a multinational scoring system for identifying low-risk febrile neutropenic cancer patients. J Clin Oncol 18(16): 3038-3051. https://doi.org/10.1200/jco.2000.18.16.3038

16. Klastersky J, Paesmans M (2013) The Multinational Association for Supportive Care in Cancer (MASCC) risk index score: 10 years of use for identifying low-risk febrile neutropenic cancer patients. Supportive care in cancer : official journal of the Multinational Association of Supportive Care in Cancer 21(5): 1487-1495. https://doi.org/10.1007/s00520-013-1758-y

17. Blijlevens NM, Logan RM, Netea MG (2009) The changing face of febrile neutropenia-from monotherapy to moulds to mucositis. Mucositis: from febrile neutropenia to febrile mucositis. J Antimicrob Chemother 63(Suppl 1):i36-i40. https://doi.org/10. 1093/jac/dkp081

18. van der Velden WJ, Blijlevens NM, Feuth T, Donnelly JP (2009) Febrile mucositis in haematopoietic SCT recipients. Bone Marrow Transplant 43(1):55-60. https://doi.org/10.1038/bmt.2008.270

19. Ruescher TJ, Sodeifi A, Scrivani SJ, Kaban LB, Sonis ST (1998) The impact of mucositis on alpha-hemolytic streptococcal infection in patients undergoing autologous bone marrow transplantation for hematologic malignancies. Cancer 82(11):2275-2281

20. Vidal AM, Sarria JC, Kimbrough RC 3rd, Keung YK (2000) Anaerobic bacteremia in a neutropenic patient with oral mucositis. Am J Med Sci 319(3):189-190

21. Stansbury DM, Peterson DE, Suzuki JB (1988) Rapidly progressive acute periodontal infection in a patient with acute leukemia. J Periodontol 59(8):544-547. https://doi.org/10.1902/jop.1988.59. 8.544

22. Schenkein HA, Loos BG (2013) Inflammatory mechanisms linking periodontal diseases to cardiovascular diseases. J Periodontol 84(4 Suppl):S51-S69. https://doi.org/10.1902/jop. 2013.134006

23. Laine PO, Lindqvist JC, Pyrhonen SO, Strand-Pettinen IM, Teerenhovi LM, Meurman JH (1992) Oral infection as a reason for febrile episodes in lymphoma patients receiving cytostatic drugs. Eur J Cancer B Oral Oncol 28b(2):103-107
24. Soga Y, Yamasuji Y, Kudo C, Matsuura-Yoshimoto K, Yamabe K, Sugiura Y, Maeda Y, Ishimaru F, Tanimoto M, Nishimura F, Takashiba S (2009) Febrile neutropenia and periodontitis: lessons from a case periodontal treatment in the intervals between chemotherapy cycles for leukemia reduced febrile neutropenia. Supportive care in cancer : official journal of the Multinational Association of Supportive Care in Cancer 17(5):581-587. https://doi.org/10.1007/s00520-008-0532-z

25. Raber-Durlacher JE, von Bultzingslowen I, Logan RM, Bowen J, Al-Azri AR, Everaus H, Gerber E, Gomez JG, Pettersson BG, Soga Y, Spijkervet FK, Tissing WJ, Epstein JB, Elad S, Lalla RV (2013) Systematic review of cytokines and growth factors for the management of oral mucositis in cancer patients. Supportive care in cancer : official journal of the Multinational Association of Supportive Care in Cancer 21(1):343-355. https://doi.org/10.1007/s00520-012-1594-5

26. van Winkelhoff AJ, Winkel EG, Vandenbroucke-Grauls CM (2001) Periodontitis: a hidden chronic infection. Ned Tijdschr Geneeskd 145(12):557-563

27. Oral complications of cancer therapies: diagnosis, prevention, and treatment (1989). Natl Inst Health Consens Dev Conf Consens Statement 7 (7):1-11

28. Kilian M, Chapple IL, Hannig M, Marsh PD, Meuric V, Pedersen AM, Tonetti MS, Wade WG, Zaura E (2016) The oral microbiome - an update for oral healthcare professionals. Br Dent J 221(10): 657-666. https://doi.org/10.1038/sj.bdj.2016.865

29. Peterson DE, Minah GE, Reynolds MA, Weikel DS, Overholser CD, DePaola LG, Wade JC, Suzuki JB (1990) Effect of granulocytopenia on oral microbial relationships in patients with acute leukemia. Oral Surg Oral Med Oral Pathol 70(6):720-723

30. Bergmann OJ (1991) Alterations in oral microflora and pathogenesis of acute oral infections during remission-induction therapy in patients with acute myeloid leukaemia. Scand J Infect Dis 23(3): 355-366

31. Napenas JJ, Brennan MT, Coleman S, Kent ML, Noll J, Frenette G, Nussbaum ML, Mougeot JL, Paster BJ, Lockhart PB, BahraniMougeot FK (2010) Molecular methodology to assess the impact of cancer chemotherapy on the oral bacterial flora: a pilot study. Oral Surg Oral Med Oral Pathol Oral Radiol Endod 109(4):554560. https://doi.org/10.1016/j.tripleo.2009.11.015

32. Ye Y, Carlsson G, Agholme MB, Karlsson-Sjoberg J, YucelLindberg T, Putsep K, Modeer T (2013) Pretherapeutic plasma pro- and anti- inflammatory mediators are related to high risk of oral mucositis in pediatric patients with acute leukemia: a prospective cohort study. PLoS One 8(5):e64918. https://doi.org/10.1371/ journal.pone.0064918

33. Galloway-Pena JR, Smith DP, Sahasrabhojane P, Ajami NJ, Wadsworth WD, Daver NG, Chemaly RF, Marsh L, Ghantoji SS, Pemmaraju N, Garcia-Manero G, Rezvani K, Alousi AM, Wargo JA, Shpall EJ, Futreal PA, Guindani M, Petrosino JF, Kontoyiannis DP, Shelburne SA (2016) The role of the gastrointestinal microbiome in infectious complications during induction chemotherapy for acute myeloid leukemia. Cancer 122(14):21862196. https://doi.org/10.1002/cncr.30039

34. Dahlen G (2009) Bacterial infections of the oral mucosa. Periodontol 49:13-38. https://doi.org/10.1111/j.1600-0757.2008. 00295.x

35. Kennedy HF, Morrison D, Kaufmann ME, Jackson MS, Bagg J, Gibson BE, Gemmell CG, Michie JR (2000) Origins of Staphylococcus epidermidis and Streptococcus oralis causing bacteraemia in a bone marrow transplant patient. J Med Microbiol 49(4):367-370. https://doi.org/10.1099/0022-1317-494-367

36. Costa SF, Miceli MH, Anaissie EJ (2004) Mucosa or skin as source of coagulase-negative staphylococcal bacteraemia? 
Lancet Infect Dis 4(5):278-286. https://doi.org/10.1016/s14733099(04)01003-5

37. Soga Y, Maeda Y, Ishimaru F, Tanimoto M, Maeda H, Nishimura F, Takashiba S (2011) Bacterial substitution of coagulase-negative staphylococci for streptococci on the oral mucosa after hematopoietic cell transplantation. Supportive care in cancer : official journal of the Multinational Association of Supportive Care in Cancer 19(7):995-1000. https://doi.org/10.1007/s00520-0100923-9

38. Soga Y, Maeda Y, Tanimoto M, Ebinuma T, Maeda H, Takashiba S (2013) Antibiotic sensitivity of bacteria on the oral mucosa after hematopoietic cell transplantation. Supportive care in cancer : official journal of the Multinational Association of Supportive Care in Cancer 21(2):367-368. https://doi.org/10.1007/s00520-0121602-9

39. Jensen SB, Mouridsen HT, Reibel J, Brunner N, Nauntofte B (2008) Adjuvant chemotherapy in breast cancer patients induces temporary salivary gland hypofunction. Oral Oncol 44(2):162173. https://doi.org/10.1016/j.oraloncology.2007.01.015

40. Nieuw Amerongen AV, Veerman EC (2003) Current therapies for xerostomia and salivary gland hypofunction associated with cancer therapies. Supportive care in cancer : official journal of the Multinational Association of Supportive Care in Cancer 11(4): 226-231. https://doi.org/10.1007/s00520-002-0409-5

41. Epstein JB, Tsang AH, Warkentin D, Ship JA (2002) The role of salivary function in modulating chemotherapy-induced oropharyngeal mucositis: a review of the literature. Oral Surg Oral Med Oral Pathol Oral Radiol Endod 94(1):39-44

42. Haverman TM, Raber-Durlacher JE, Rademacher WM, Vokurka S, Epstein JB, Huisman C, Hazenberg MD, de Soet JJ, de Lange J, Rozema FR (2014) Oral complications in hematopoietic stem cell recipients: the role of inflammation. Mediat Inflamm 2014: 378281. https://doi.org/10.1155/2014/378281

43. Dewhirst FE, Chen T, Izard J, Paster BJ, Tanner AC, Yu WH, Lakshmanan A, Wade WG (2010) The human oral microbiome. J Bacteriol 192(19):5002-5017. https://doi.org/10.1128/jb.0054210

44. Lockhart PB, Brennan MT, Sasser HC, Fox PC, Paster BJ, Bahrani-Mougeot FK (2008) Bacteremia associated with toothbrushing and dental extraction. Circulation 117(24):3118-3125. https://doi.org/10.1161/circulationaha.107.758524

45. Papapanou PN (2015) Systemic effects of periodontitis: lessons learned from research on atherosclerotic vascular disease and adverse pregnancy outcomes. Int Dent J 65(6):283-291. https://doi. org/10.1111/idj.12185

46. Bergmann OJ, Kilian M, Ellegaard J (1989) Potentially pathogenic microorganisms in the oral cavity during febrile episodes in immunocompromised patients with haematologic malignancies. Scand J Infect Dis 21(1):43-51

47. Graber CJ, de Almeida KN, Atkinson JC, Javaheri D, Fukuda CD, Gill VJ, Barrett AJ, Bennett JE (2001) Dental health and viridans streptococcal bacteremia in allogeneic hematopoietic stem cell transplant recipients. Bone Marrow Transplant 27(5):537-542. https://doi.org/10.1038/sj.bmt.1702818

48. Sonis ST, Oster G, Fuchs H, Bellm L, Bradford WZ, Edelsberg J, Hayden V, Eilers J, Epstein JB, LeVeque FG, Miller C, Peterson DE, Schubert MM, Spijkervet FK, Horowitz M (2001) Oral mucositis and the clinical and economic outcomes of hematopoietic stem-cell transplantation. J Clin Oncol 19(8):2201-2205

49. Rapoport AP, Miller Watelet LF, Linder T, Eberly S, Raubertas RF, Lipp J, Duerst R, Abboud CN, Constine L, Andrews J, Etter MA, Spear L, Powley E, Packman CH, Rowe JM, Schwertschlag U, Bedrosian C, Liesveld JL (1999) Analysis of factors that correlate with mucositis in recipients of autologous and allogeneic stem-cell transplants. J Clin Oncol 17(8):2446-2453. https://doi. org/10.1200/jco.1999.17.8.2446
50. Fanning SR, Rybicki L, Kalaycio M, Andresen S, Kuczkowski E, Pohlman B, Sobecks R, Sweetenham J, Bolwell B (2006) Severe mucositis is associated with reduced survival after autologous stem cell transplantation for lymphoid malignancies. Br J Haematol 135(3):374-381. https://doi.org/10.1111/j.1365-2141. 2006.06323.x

51. Wong HM (2014) Oral complications and management strategies for patients undergoing cancer therapy. ScientificWorldJournal 2014:581795. https://doi.org/10.1155/2014/581795

52. Wuketich S, Hienz SA, Marosi C (2012) Prevalence of clinically relevant oral mucositis in outpatients receiving myelosuppressive chemotherapy for solid tumors. Supportive care in cancer : official journal of the Multinational Association of Supportive Care in Cancer 20(1):175-183. https://doi.org/10.1007/s00520-0111107-y

53. Kashiwazaki H, Matsushita T, Sugita J, Shigematsu A, Kasashi K, Yamazaki Y, Kanehira T, Yamamoto S, Kondo T, Endo T, Tanaka J, Hashino S, Nishio M, Imamura M, Kitagawa Y, Inoue N (2012) Professional oral health care reduces oral mucositis and febrile neutropenia in patients treated with allogeneic bone marrow transplantation. Supportive care in cancer : official journal of the Multinational Association of Supportive Care in Cancer 20(2): 367-373. https://doi.org/10.1007/s00520-011-1116-x

54. Khan SA, Wingard JR (2001) Infection and mucosal injury in cancer treatment. J Natl Cancer Inst Monogr 2001(29):31-36

55. Sonis ST, Elting LS, Keefe D, Peterson DE, Schubert M, HauerJensen M, Bekele BN, Raber-Durlacher J, Donnelly JP, Rubenstein EB (2004) Perspectives on cancer therapy-induced mucosal injury: pathogenesis, measurement, epidemiology, and consequences for patients. Cancer 100(9 Suppl):1995-2025. https://doi.org/10.1002/cncr.20162

56. Jensen SB, Mouridsen HT, Bergmann OJ, Reibel J, Brunner N, Nauntofte B (2008) Oral mucosal lesions, microbial changes, and taste disturbances induced by adjuvant chemotherapy in breast cancer patients. Oral Surg Oral Med Oral Pathol Oral Radiol Endod 106(2):217-226. https://doi.org/10.1016/j.tripleo.2008.04. 003

57. Al Ibraheemi AA, Shamoun S (2016) Incidence and risk factors of oral mucositis in patients with breast cancer who receiving chemotherapy in Al-Bashir hospital. Int J Hematol Oncol Stem Cell Res 10(4):217-223

58. Nishimura N, Nakano K, Ueda K, Kodaira M, Yamada S, Mishima Y, Yokoyama M, Terui Y, Takahashi S, Hatake K (2012) Prospective evaluation of incidence and severity of oral mucositis induced by conventional chemotherapy in solid tumors and malignant lymphomas. Supportive care in cancer : official journal of the Multinational Association of Supportive Care in Cancer 20(9):2053-2059. https://doi.org/10.1007/s00520-011$1314-6$

59. Laine PO, Lindqvist JC, Pyrhonen SO, Teerenhovi LM, Syrjanen SM, Meurman JH (1993) Lesions of the oral mucosa in lymphoma patients receiving cytostatic drugs. Eur J Cancer B Oral Oncol 29b(4):291-294

60. Blijlevens NM, Donnelly JP, de Pauw BE (2001) Empirical therapy of febrile neutropenic patients with mucositis: challenge of risk-based therapy. Clin Microbiol Infect 7(Suppl 4):47-52

61. McCann S, Schwenkglenks M, Bacon P, Einsele H, D'Addio A, Maertens J, Niederwieser D, Rabitsch W, Roosaar A, Ruutu T, Schouten H, Stone R, Vorkurka S, Quinn B, Blijlevens N (2009) The prospective oral mucositis audit: relationship of severe oral mucositis with clinical and medical resource use outcomes in patients receiving high-dose melphalan or BEAM-conditioning chemotherapy and autologous SCT. Bone Marrow Transplant 43(2): 141-147. https://doi.org/10.1038/bmt.2008.299

62. Schuurhuis JM, Span LF, Stokman MA, van Winkelhoff AJ, Vissink A, Spijkervet FK (2016) Effect of leaving chronic oral 
foci untreated on infectious complications during intensive chemotherapy. Br J Cancer 114(9):972-978. https://doi.org/10.1038/ bjc. 2016.60

63. Sonis ST (2010) New thoughts on the initiation of mucositis. Oral Dis 16(7):597-600. https://doi.org/10.1111/j.1601-0825.2010. 01681.x

64. Russi EG, Raber-Durlacher JE, Sonis ST (2014) Local and systemic pathogenesis and consequences of regimen-induced inflammatory responses in patients with head and neck cancer receiving chemoradiation. Mediat Inflamm 2014:518261. https://doi.org/10. $1155 / 2014 / 518261$

65. Greenberg MS, Cohen SG, McKitrick JC, Cassileth PA (1982) The oral flor as a source of septicemia in patients with acute leukemia. Oral Surg Oral Med Oral Pathol 53(1):32-36

66. Djuric M, Hillier-Kolarov V, Belic A, Jankovic L (2006) Mucositis prevention by improved dental care in acute leukemia patients. Supportive care in cancer : official journal of the Multinational Association of Supportive Care in Cancer 14(2): 137-146. https://doi.org/10.1007/s00520-005-0867-7

67. Fernandes LL, Torres SR, Garnica M, de Souza Goncalves L, Junior AS, de Vasconcellos AC, Cavalcanti W, Maiolino A, de Barros Torres MC (2014) Oral status of patients submitted to autologous hematopoietic stem cell transplantation. Supportive care in cancer : official journal of the Multinational Association of Supportive Care in Cancer 22(1):15-21. https://doi.org/10. 1007/s00520-013-1940-2

68. Borowski B, Benhamou E, Pico JL, Laplanche A, Margainaud JP, Hayat M (1994) Prevention of oral mucositis in patients treated with high-dose chemotherapy and bone marrow transplantation: a randomised controlled trial comparing two protocols of dental care. Eur J Cancer B Oral Oncol 30b(2):93-97

69. Dodd MJ, Miaskowski C, Shiba GH, Dibble SL, Greenspan D, MacPhail L, Paul SM, Larson P (1999) Risk factors for chemotherapy-induced oral mucositis: dental appliances, oral hygiene, previous oral lesions, and history of smoking. Cancer Investig 17(4):278-284

70. Santos PS, Coracin FL, Barros JC, Dulley FL, Nunes FD, Magalhaes MG (2011) Impact of oral care prior to HSCT on the severity and clinical outcomes of oral mucositis. Clin Transpl 25(2):325-328. https://doi.org/10.1111/j.1399-0012.2010.01283. $\mathrm{x}$

71. Coracin FL, Santos PS, Gallottini MH, Saboya R, Musqueira PT, Barban A, Chamone Dde A, Dulley FL, Nunes FD (2013) Oral health as a predictive factor for oral mucositis. Clinics (Sao Paulo) 68(6):792-796. https://doi.org/10.6061/clinics/2013(06)11

72. Gurgan CA, Ozcan M, Karakus O, Zincircioglu G, Arat M, Soydan E, Topcuoglu P, Gurman G, Bostanci HS (2013) Periodontal status and post-transplantation complications following intensive periodontal treatment in patients underwent allogenic hematopoietic stem cell transplantation conditioned with myeloablative regimen. Int J Dent Hyg 11(2):84-90. https://doi. org/10.1111/j.1601-5037.2012.00550.x

73. Epstein JB, Schubert MM (1999) Oral mucositis in myelosuppressive cancer therapy. Oral Surg Oral Med Oral Pathol Oral Radiol Endod 88(3):273-276

74. Elting LS, Bodey GP, Keefe BH (1992) Septicemia and shock syndrome due to viridans streptococci: a case-control study of predisposing factors. Clin Infect Dis 14(6):1201-1207

75. Bochud PY, Calandra T, Francioli P (1994) Bacteremia due to viridans streptococci in neutropenic patients: a review. Am J Med 97(3):256-264

76. Marron A, Carratala J, Gonzalez-Barca E, Fernandez-Sevilla A, Alcaide F, Gudiol F (2000) Serious complications of bacteremia caused by Viridans streptococci in neutropenic patients with cancer. Clin Infect Dis 31(5):1126-1130. https://doi.org/10.1086/ 317460
77. Ebinuma T, Soga Y, Sato T, Matsunaga K, Kudo C, Maeda H, Maeda Y, Tanimoto M, Takashiba S (2014) Distribution of oral mucosal bacteria with mecA in patients undergoing hematopoietic cell transplantation. Supportive care in cancer : official journal of the Multinational Association of Supportive Care in Cancer 22(6): 1679-1683. https://doi.org/10.1007/s00520-014-2151-1

78. Chen YK, Hou HA, Chow JM, Chen YC, Hsueh PR, Tien HF (2011) The impact of oral herpes simplex virus infection and candidiasis on chemotherapy-induced oral mucositis among patients with hematological malignancies. Eur J Clin Microbiol Infect Dis 30(6):753-759. https://doi.org/10.1007/s10096-010-1148-Z

79. Logan RM, Stringer AM, Bowen JM, Gibson RJ, Sonis ST, Keefe DM (2008) Serum levels of NFkappaB and pro-inflammatory cytokines following administration of mucotoxic drugs. Cancer Biol Ther 7(7):1139-1145

80. van der Beek MT, Laheij AM, Raber-Durlacher JE, von dem Borne PA, Wolterbeek R, van der Blij-de Brouwer CS, van Loveren C, Claas EC, Kroes AC, de Soet JJ, Vossen AC (2012) Viral loads and antiviral resistance of herpesviruses and oral ulcerations in hematopoietic stem cell transplant recipients. Bone Marrow Transplant 47(9):1222-1228. https://doi.org/10.1038/ bmt.2012.2

81. Contreras A, Botero JE, Slots J (2014) Biology and pathogenesis of cytomegalovirus in periodontal disease. Periodontol 64(1):40 56. https://doi.org/10.1111/j.1600-0757.2012.00448.x

82. Correia-Silva JF, Bruna-Romero O, Resende RG, Miranda LP, Oliveira FE, Costa FO, Xavier SG, Figueiredo-Neves SP, Almeida HC, Bittencourt H, Gomez RS (2010) Saliva as a source of HCMV DNA in allogeneic stem cell transplantation patients. Oral Dis 16(2):210-216. https://doi.org/10.1111/j.1601-0825. 2009.01637.x

83. Wingard JR, Hsu J, Hiemenz JW (2010) Hematopoietic stem cell transplantation: an overview of infection risks and epidemiology. Infect Dis Clin N Am 24(2):257-272. https://doi.org/10.1016/j. idc. 2010.01 .010

84. Lalla RV, Latortue MC, Hong $\mathrm{CH}$, Ariyawardana A, D'AmatoPalumbo S, Fischer DJ, Martof A, Nicolatou-Galitis O, Patton LL, Elting LS, Spijkervet FK, Brennan MT (2010) A systematic review of oral fungal infections in patients receiving cancer therapy. Supportive care in cancer : official journal of the Multinational Association of Supportive Care in Cancer 18(8): 985-992. https://doi.org/10.1007/s00520-010-0892-z

85. Dongari-Bagtzoglou A, Fidel PL Jr (2005) The host cytokine responses and protective immunity in oropharyngeal candidiasis. $\mathrm{J}$ Dent Res 84(11):966-977. https://doi.org/10.1177/ 154405910508401101

86. Wingard JR, Leather HL (2001) Empiric antifungal therapy for the neutropenic patient. Oncology (Williston Park) 15(3):351-363 discussion 363-354, 367-359

87. Deepa A, Nair BJ, Sivakumar T, Joseph AP (2014) Uncommon opportunistic fungal infections of oral cavity: a review. J Oral Maxillofac Pathol 18(2):235-243. https://doi.org/10.4103/0973029x.140765

88. Chambers MS, Toth BB, Martin JW, Fleming TJ, Lemon JC (1995) Oral and dental management of the cancer patient: prevention and treatment of complications. Supportive care in cancer : official journal of the Multinational Association of Supportive Care in Cancer 3(3):168-175

89. Kinane DF, Stathopoulou PG, Papapanou PN (2017) Periodontal diseases. Nat Rev Dis Primers 3:17038. https://doi.org/10.1038/ nrdp. 2017.38

90. Paraskevas S, Huizinga JD, Loos BG (2008) A systematic review and meta-analyses on C-reactive protein in relation to periodontitis. J Clin Periodontol 35(4):277-290. https://doi.org/10.1111/j. 1600-051X.2007.01173.x 
91. Almaghlouth AA, Cionca N, Cancela JA, Decaillet F, Courvoisier DS, Giannopoulou C, Mombelli A (2014) Effect of periodontal treatment on peak serum levels of inflammatory markers. Clin Oral Investig 18(9):2113-2121. https://doi.org/10.1007/s00784014-1187-4

92. Beck J, Garcia R, Heiss G, Vokonas PS, Offenbacher S (1996) Periodontal disease and cardiovascular disease. J Periodontol 67(Suppl 10S):1123-1137. https://doi.org/10.1902/jop.1996.67. 10 s. 1123

93. Linden GJ, Lyons A, Scannapieco FA (2013) Periodontal systemic associations: review of the evidence. J Periodontol 84(4 Suppl): S8-s19. https://doi.org/10.1902/jop.2013.1340010

94. Loesche WJ, Lopatin DE (1998) Interactions between periodontal disease, medical diseases and immunity in the older individual. Periodontol 16:80-105

95. Maddi A, Scannapieco FA (2013) Oral biofilms, oral and periodontal infections, and systemic disease. Am J Dent 26(5):249254

96. Raber-Durlacher JE, Epstein JB, Raber J, van Dissel JT, van Winkelhoff AJ, Guiot HF, van der Velden U (2002) Periodontal infection in cancer patients treated with high-dose chemotherapy. Supportive care in cancer : official journal of the Multinational Association of Supportive Care in Cancer 10(6):466-473. https:// doi.org/10.1007/s00520-002-0346-3

97. Hong CH, Napenas JJ, Hodgson BD, Stokman MA, MathersStauffer V, Elting LS, Spijkervet FK, Brennan MT (2010) A systematic review of dental disease in patients undergoing cancer therapy. Supportive care in cancer : official journal of the Multinational Association of Supportive Care in Cancer 18(8): 1007-1021. https://doi.org/10.1007/s00520-010-0873-2

98. Peterson DE, Overholser CD (1981) Increased morbidity associated with oral infection in patients with acute nonlymphocytic leukemia. Oral Surg Oral Med Oral Pathol 51(4):390-393

99. Overholser CD, Peterson DE, Williams LT, Schimpff SC (1982) Periodontal infection in patients with acute nonlymphocyte leukemia. Prevalence of acute exacerbations. Arch Intern Med 142(3): 551-554

100. Meurman JH, Pyrhonen S, Teerenhovi L, Lindqvist C (1997) Oral sources of septicaemia in patients with malignancies. Oral Oncol 33(6):389-397

101. van Winkelhoff AJ, Slots J (1999) Actinobacillus actinomycetemcomitans and Porphyromonas gingivalis in nonoral infections. Periodontol 20:122-135

102. Baquero F, Fernandez J, Dronda F, Erice A, Perez de Oteiza J, Reguera JA, Reig M (1990) Capnophilic and anaerobic bacteremia in neutropenic patients: an oral source. Rev Infect Dis 12(Suppl 2):S157-S160

103. Bilgrami S, Bergstrom SK, Peterson DE, Hill DR, Dainiak N, Quinn JJ, Ascensao JL (1992) Capnocytophaga bacteremia in a patient with Hodgkin's disease following bone marrow transplantation: case report and review. Clin Infect Dis 14(5):1045-1049

104. Landsaat PM, van der Lelie H, Bongaerts G, Kuijper EJ (1995) Fusobacterium nucleatum, a new invasive pathogen in neutropenic patients? Scand J Infect Dis 27(1):83-84

105. Fanourgiakis P, Vekemans M, Georgala A, Daneau D, Vandermies A, Grenier P, Aoun M (2003) Febrile neutropenia and Fusobacterium bacteremia: clinical experience with 13 cases. Supportive care in cancer : official journal of the Multinational Association of Supportive Care in Cancer 11(5):332-335. https://doi.org/10.1007/s00520-003-0452-x

106. Terhes G, Piukovics K, Urban E, Nagy E (2011) Four cases of bacteraemia caused by Fusobacterium nucleatum in febrile, neutropenic patients. J Med Microbiol 60 (Pt 7:1046-1049. https:// doi.org/10.1099/jmm.0.026351-0

107. Raber-Durlacher JE, Laheij AM, Epstein JB, Epstein M, Geerligs GM, Wolffe GN, Blijlevens NM, Donnelly JP (2013) Periodontal status and bacteremia with oral viridans streptococci and coagulase negative staphylococci in allogeneic hematopoietic stem cell transplantation recipients: a prospective observational study. Supportive care in cancer : official journal of the Multinational Association of Supportive Care in Cancer 21(6):1621-1627. https://doi.org/10.1007/s00520-012-1706-2

108. Toljanic JA, Bedard JF, Larson RA, Fox JP (1999) A prospective pilot study to evaluate a new dental assessment and treatment paradigm for patients scheduled to undergo intensive chemotherapy for cancer. Cancer 85(8):1843-1848

109. Akintoye SO, Brennan MT, Graber CJ, McKinney BE, Rams TE, Barrett AJ, Atkinson JC (2002) A retrospective investigation of advanced periodontal disease as a risk factor for septicemia in hematopoietic stem cell and bone marrow transplant recipients. Oral Surg Oral Med Oral Pathol Oral Radiol Endod 94(5):581588

110. Hong CHL, Hu S, Haverman T, Stokman M, Napenas JJ, Braber JB, Gerber E, Geuke M, Vardas E, Waltimo T, Jensen SB, Saunders DP (2018) A systematic review of dental disease management in cancer patients. Supportive care in cancer : official journal of the Multinational Association of Supportive Care in Cancer 26(1):155-174. https://doi.org/10.1007/s00520-0173829-y

111. Tsuji K, Shibuya Y, Akashi M, Furudoi S, Yakushijin K, Kawamoto S, Okamura A, Matsuoka H, Komori T (2015) Prospective study of dental intervention for hematopoietic malignancy. J Dent Res 94(2):289-296. https://doi.org/10.1177/ 0022034514561768

112. Akashi M, Shibuya Y, Kusumoto J, Furudoi S, Inui Y, Yakushijin K, Okamura A, Matsuoka H, Komori T (2013) Myelosuppression grading of chemotherapies for hematologic malignancies to facilitate communication between medical and dental staff: lessons from two cases experienced odontogenic septicemia. BMC Oral Health 13:41. https://doi.org/10.1186/1472-6831-13-41

113. Forner L, Larsen T, Kilian M, Holmstrup P (2006) Incidence of bacteremia after chewing, tooth brushing and scaling in individuals with periodontal inflammation. J Clin Periodontol 33(6):401407. https://doi.org/10.1111/j.1600-051X.2006.00924.x

114. Scannapieco FA (2006) Pneumonia in nonambulatory patients. The role of oral bacteria and oral hygiene. J Am Dent Assoc 137 Suppl:21s-25s

115. Heimdahl A, Gahrton G, Groth CG, Lundgren G, Lonnquist B, Ringden O, Nord CE (1984) Selective decontamination of alimentary tract microbial flora in patients treated with bone marrow transplantation. A microbiological study. Scand J Infect Dis 16(1):51-60

116. Galili D, Donitza A, Garfunkel A, Sela MN (1992) Gram-negative enteric bacteria in the oral cavity of leukemia patients. Oral Surg Oral Med Oral Pathol 74(4):459-462

117. Sixou JL, De Medeiros-Batista O, Gandemer V, Bonnaure-Mallet M (1998) The effect of chemotherapy on the supragingival plaque of pediatric cancer patients. Oral Oncol 34(6):476-483

118. Soares AF, Aquino AR, Carvalho CH, Nonaka CF, Almeida D, Pinto LP (2011) Frequency of oral mucositis and microbiological analysis in children with acute lymphoblastic leukemia treated with $0.12 \%$ chlorhexidine gluconate. Braz Dent J 22(4):312-316

119. de Mendonca RM, de Araujo M, Levy CE, Morari J, Silva RA, Yunes JA, Brandalise SR (2012) Prospective evaluation of HSV, Candida spp., and oral bacteria on the severity of oral mucositis in pediatric acute lymphoblastic leukemia. Supportive care in cancer : official journal of the Multinational Association of Supportive Care in Cancer 20(5):1101-1107. https://doi.org/10.1007/s00520011-1190-0

120. Logan RM, Stringer AM, Bowen JM, Yeoh AS, Gibson RJ, Sonis ST, Keefe DM (2007) The role of pro-inflammatory cytokines in cancer treatment-induced alimentary tract mucositis: 
pathobiology, animal models and cytotoxic drugs. Cancer Treat Rev 33(5):448-460. https://doi.org/10.1016/j.ctrv.2007.03.001

121. Hasturk H, Kantarci A, Van Dyke TE (2012) Oral inflammatory diseases and systemic inflammation: role of the macrophage. Front Immunol 3:118. https://doi.org/10.3389/fimmu.2012.00118

122. Golub LM, Payne JB, Reinhardt RA, Nieman G (2006) Can systemic diseases co-induce (not just exacerbate) periodontitis? A hypothetical "two-hit" model. J Dent Res 85(2):102-105. https:// doi.org/10.1177/154405910608500201

123. Khaw A, Logan R, Keefe D, Bartold M (2014) Radiation-induced oral mucositis and periodontitis - proposal for an inter-relationship. Oral Dis 20 (3):e7-18. doi:https://doi.org/10.1111/odi.12199

124. Touyz LZ (2013) Periodontitis contributes to initiation, progress and aggravation of septic shock; a feasible hypothesis. Med Hypotheses 81(4):650-652. https://doi.org/10.1016/j.mehy.2013. 06.033

125. Schuurhuis JM, Stokman MA, Roodenburg JL, Reintsema H, Langendijk JA, Vissink A, Spijkervet FK (2011) Efficacy of routine pre-radiation dental screening and dental follow-up in head and neck oncology patients on intermediate and late radiation effects. A retrospective evaluation. Radiotherapy and oncology : journal of the European Society for Therapeutic Radiology and Oncology 101(3):403-409. https://doi.org/10.1016/j.radonc.2011. 09.018

126. Seto BG, Kim M, Wolinsky L, Mito RS, Champlin R (1985) Oral mucositis in patients undergoing bone marrow transplantation. Oral Surg Oral Med Oral Pathol 60(5):493-497
127. Yamagata K, Onizawa K, Yanagawa T, Hasegawa Y, Kojima H, Nagasawa T, Yoshida H (2006) A prospective study to evaluate a new dental management protocol before hematopoietic stem cell transplantation. Bone Marrow Transplant 38(3):237-242. https:// doi.org/10.1038/sj.bmt.1705429

128. Soga Y, Sugiura Y, Takahashi K, Nishimoto H, Maeda Y, Tanimoto M, Takashiba S (2010) Progress of oral care and reduction of oral mucositis-a pilot study in a hematopoietic stem cell transplantation ward. Supportive care in cancer : official journal of the Multinational Association of Supportive Care in Cancer 19(2): 303-307. https://doi.org/10.1007/s00520-010-1002-y

129. Elad S, Thierer T, Bitan M, Shapira MY, Meyerowitz C (2008) A decision analysis: the dental management of patients prior to hematology cytotoxic therapy or hematopoietic stem cell transplantation. Oral Oncol 44(1):37-42. https://doi.org/10.1016/j. oraloncology.2006.12.006

130. Bartold PM, Van Dyke TE (2013) Periodontitis: a host-mediated disruption of microbial homeostasis. Unlearning learned concepts. Periodontol 2000 62(1):203-217. https://doi.org/10.1111/j.16000757.2012.00450.x

Publisher's note Springer Nature remains neutral with regard to jurisdictional claims in published maps and institutional affiliations. 